\title{
SECRETARIAL NOTES
}

The Casualty Actuarial Society celebrated its 5oth Anniversary at the meeting of the Society held at the Plaza Hotel, New York on I8th, Igth and 2oth November 1964. Five ASTIN members from Europe had been able to accept the invitation to attend the meetings and took an active part in the proceedings. Apart from interventions during the varied programme of topics for discussion, the ASTIN members took part in a panel discussion on Motor Insurance-Hans Ammeter on Switzerland, R. E. Beard on the United Kingdom, K. Borch on Norway, B. Christoffersen on Denmark and E. Franckx on Belgium. Papers were also presented by $K$. Borch and E. Franckx. During the banquet, our Chairman, Dr. Ammeter, presented a pewter jug to the Society with the following engraving:

Presented to the

CASUALTY ACTUARIAL SOCIETY
by
ASTIN
I964

In presenting the gift our Chairman expressed greetings from ASTIN in a characteristic fashion and the President of the Society suitably expressed his thanks.

The meetings were an undoubted success both from the papers presented, the standard of technical discussion and the social aspects and form a valuable record of the past history of the Society and a happy augury for the future.

Our sincerest congratulations are due to our Chairman, Hans Ammeter, who was awarded an honorary doctorate (Dr. sc. math. h.c.) by the Swiss Federal University (ETH). We are all well aware of the many significant contributions he has made to Actuarial Science and to ASTIN in particular and it is particularly happy that this award has been made during his term of office as Chairman.

Members of ASTIN will be pleased to learn that one of our founder members, Dr. Paul Johansen, has recently been awarded the Ridder of Dannebroge. We offer our congratulations for this award which no doubt is linked up with his distinguished contributions to actuarial science.

Members may have noted a falling off in the Secretarial service during the last quarter of 1964 . This was occasioned by the visit of $\mathrm{R}$. E. Beard to Australia and New Zealand prior to visiting New York. During his visit to these countries he was invited to address meetings of resident actuaries and to talk about the activities of ASTIN. In both countries the non-life insurers are experiencing similar difficulties to those which have marked the European and $\mathbf{N}$. American scene in recent years, particularly in the field of motor insurance, and the exchange of views was of considerable interest and value. 
Arrangements for the $5^{\text {th }}$ Colloquium are well advanced by the Swiss Actuarial Society and at the turn of the year a record number of 120 members had indicated their intention of travelling to Lucerne to join in the meetings. The subjects for discussion not only cover theoretical aspects but the opportunity for further discussion on practical aspects, particularly those arising from motor insurance and the problems of control should lead to a lively and constructive meeting.

The presence of four committee members in New York provided an opportunity of a committee meeting to discuss detailed matters arising from the 1965 Colloquium and other routine administrative topics.

A further communication has been received from the Secretary to the 6th Conference of European Insurance Supervisory Services to be held in May I966. A preliminary report on the subject of the calculation of nonlife insurance reserves was prepared by the Secretary of ASTIN and circulated to members of the committee, and will be presented for discussion during the Lucerne colloquium. Suggestions for further co-operation by members of ASTIN will also be put forward for discussion.

The deaths of two active ASTIN members have been noted with sincere regrets, Thomas O. Carlson on I5th July I964 and G. Lutfalla on 8th October r964 and brief obituary notes follow:

\section{Thomas O. Carlson,}

Past President of the Casualty Actuarial Society, and Southeastern Branch Manager of the National Bureau of Casualty Underwriters, died of a heart attack in Berkeley County Hospital, Moncks Corner, South Carolina, on July I5, I964, at the age of 59 .

Mr. Carlson was born in Shoreham, Vermont, and was educated at Middlebury College, Vermont, and at New York University where he receined a Master of Science degree. He started his insurance career with the Aetna Casualty and Surety Company at Hartford and in I923 joined the National Bureau of Casualty Underwriters, the organisation which makes the rates for automobile and other lines of casualty insurance for Stock agency companies throughout the United States of America. He became assistant actuary of the Bureau in 1932 and actuary in 1944.

Mr. Carlson contributed greatly to the development of the Casualty Actuarial Society. He trained some of the most brilliant of the younger members of the Society and took a major interest in the Society's Educational programme, $\mathrm{He}$ contributed greatly to the cause of scientific rate making by speeches and articles. His study, "Rate Regulation and the Casualty Actuary" and his chapters on rate making in G. F. Michelbacher's "Multiple Line Insurance" are both extensively used in college insurance courses. His "Negative Binomial Rationale" which was presented to the November, 1962 meeting of the Casualty Actuarial Society was exceptionally stimulating and illustrated his able grasp of technical problems.

He presented a paper "Observations on casualty insurance rate making theory in the United States" under Subject 4 of the recent I 7 th International Congress of Actuaries in London. The strongly practical aspects of this report contrasted noticeably with the highly theoretical nature of most of the other contributions on the subject.

$\mathrm{He}$ is survived by his widow, a daughter and two sons. 
George Lutfalla

died on the 8 th October at the age of 60 after a short illness which necessitated a surgical operation. He was a familiar figure at the ASTIN colloquia to the success of which he helped by his valuable interventions in the discussions and in informal conversations.

He was one of the leading figures in French insurance circles and made many contributions to both the commercial and technical aspects of the business, his abilities being recognised in his appointment as PrésidentDirecteur Général of the Nationa1-Risques Divers and the National-Réassurances.

Social and economic questions were dear to his heart and since 1947 he was a member of the "Conseil Economique et Social"; for many years he was editor of La Revue d'Economie Politique and was Administrateur Général de l'Ecole National d'Organisation Economique et Sociale.

To all of his activities he brought an active, intelligent and constructive mind. He was a good friend with a warm heart and whose loss will be keenly felt.

He is survived by his widow and two sons. 